\title{
Max Weber and W.E.B. Du Bois on Color Line
}

HONDA Kazuhisa

\section{Introduction: Academic Interaction between German and American Sociologists}

American and German sociologies have a long history of interaction and mutual development. Talcott Parsons is generally regarded as the first American sociologist to introduce German sociological studies to the U.S. by writing The Structure of Social Action in 1937 and translating Max Weber's 1904-05 work The Protestant Ethic and the Spirit of Capitalism in 1930, which had a profound impact on the advancement of American sociology in the 20th century.

However, earlier than Parsons, in fact, African American sociologist W.E.B. Du Bois interacted with German sociologists including Max Weber while he studied in Berlin from 1892 to 1894. This had an enormous influence on his sociological empirical researches about the "Negro Problem" in the South after returning to the U.S., one of which resulted in The Philadelphia Negro: A Social Study in 1899 (Anderson 1996: xii-xiii).

On the other hand, Max Weber was deeply interested in the American modern capitalist society, and he completed one of his masterpieces Die protestantische Ethik und der Geist des Kapitalismus after taking part in the Congress of Arts and Science in St. Louis, Missouri, traveling around the U.S. and meeting many American people including Du Bois in 1904.

In 2011, Professor Lawrence Scaff published a distinguished work, Max Weber in America, which details Weber's academic works and three-month journey around the U.S., with his wide intellectual interests in American society, capitalist economy, lifestyle, culture, religion, democracy, racism, and so on. While referring to some parts of Professor Scaff's excellent studies on Max Weber and his interaction with Du Bois, this paper ${ }^{(1)}$ will mainly focus upon 1) Du Bois's sociological understanding of racism in the U.S. around 1900, 2) the ideas of Du Bois and his rival Booker T. Washington on education and civil rights for African Americans, 3) Du Bois's critical understanding of Washington's conciliatory and gradualist approach for racial justice, and 4) Weber's allegedly optimistic expectation of Washington's Tuskegee Institute, which provided African Americans with a basic industrial education for a better future. This last point leads to one question: Why did Weber support Washington more enthusiastically than Du Bois, despite Weber's theory of leaders' political roles for social change, which is essentially similar to Du Bois's theory of the "talented tenth" and their noblesse oblige for racial justice?

\section{Du Bois's Sociological Studies on Domination based on Racism}

The U.S. has a long history of exclusion and discrimination against ethnic and racial minorities, especially African Americans, which dates back to the age of slavery and persistently continued even after the Emancipation Proclamation of 1863. It was widely believed among conservative whites in the U.S. that African Americans were genetically inferior to white people; this belief would not be changed through racial integration and 
equal education for both races. An ideology of white supremacy legitimized racial segregation in many spheres of American society.

W.E.B. Du Bois (1868-1963) tried to prove through his sociological studies of the "Negro Problem" that "economic and cultural backwardness" including ignorance, poverty, and crimes, among other things, did not result from the hereditary and unchangeable nature of African Americans as an "inferior race," as pseud-scientific eugenics often explained (Du Bois 1899; Du Bois 1945: 45; Du Bois 1946: 37; Anderson 1996: xvii). Rather, these were historical and structural consequences of a vicious circle in which whites' irrational racial prejudice against blacks reinforced the undeniable realities of African Americans' economic poverty and social ills and vice versa, strengthening the structuration of racial hierarchy. In addition, southern states successively institutionalized racial policies like segregation based upon the color of skin at the end of the 19th century, which was upheld by the Plessy $v$. Ferguson decision of the U.S. Supreme Court in 1896. Later, Du Bois described American racism as a "legal fascist caste system" (Du Bois 1945: 71) that would be difficult if not impossible to overcome, as white people vehemently resisted racial equality and tried to maintain their racial superiority while African Americans remained economically, socially, and culturally disadvantaged as politics failed to intervene in the structure of racism.

How, then, did Du Bois think it would be possible to solve the "Negro Problem"?

\section{Du Bois's Positive Understanding of Washington's Industrial Education}

Throughout his academic works, Du Bois claimed that defeating whites' racist prejudice would be one of the conditions for moving toward racial equality. However, Du Bois was neither naïve nor optimistic enough to believe that racism would disappear in the U.S. without African Americans making their own efforts to uplift themselves. As Gates, Jr. explained, one of Du Bois's prestigious works, The Souls of Black Folk of 1903, shows his belief that "ignorance, rather than a primal xenophobia or economic relationships, was the primary cause of racism” (1989: ix). In order for African Americans to empower themselves and become economically independent, Du Bois emphasized the importance of education for all African Americans. In this sense, it seems that Du Bois's proposal for equal education was similar to the principle of his rival Booker T. Washington's famous Tuskegee Institute, at least until his The Souls of Black Folk was published in 1903.

Washington founded the Tuskegee Institute in Alabama in 1881 for the purpose of providing African American youth with basic industrial training and helping them overcome their economic and social disadvantages. He believed that to solve whites' racial prejudice against blacks, they should obtain basic vocational skills for agriculture ${ }^{(2)}$, domestic jobs, mechanics, and construction, among other things: "The individual who can do something that the world wants done will, in the end, make his way regardless of his race" (Washington 1901: 154). According to Washington, students of Tuskegee Institute trained to produce and sell bricks to local white residents, who "found out that ours were good bricks" and bought them even though they had no sympathy for the institution (Ibid.: 152). Contributing to the "wealth and comfort of the community," the Tuskegee Institute and its students helped white people recognize the merit of African Americans, "no matter under what colour of skin merit is found" (Ibid.: 152-153).

On September 18, 1895, Washington delivered a conciliatory address for racial harmony 
and "mutual progress" at the Cotton States and International Exposition in Atlanta, Georgia ${ }^{(3)}$, which attracted praise and admiration from a wide range of Americans (Ibid.: 211-218), including the Governor of Georgia Rufus Brown Bullock, President Grover Cleveland, and President Theodor Roosevelt ${ }^{(4)}$. In this speech, Washington emphasized the significance of basic vocational training for African Americans, which he expected would uplift black masses and provide them with wider economic opportunities. As a result of economic independence based upon racial harmony, instead of racial confrontation, the advancement of African Americans would be anticipated even in a gradual manner according to Washington.

$\mathrm{Du}$ Bois agreed with the ideal of the Tuskegee Institute and Washington's appeal for practical vocational training for poor black masses. Though Du Bois would become severely critical of Washington's conciliatory policy sometime later, he actually sent a letter to Washington praising his successful Atlanta speech on September 24, 1895, just one week after the speech (Aptheker ed. 1985: 39). In fact, according to Manning Marable, Du Bois was not antagonistic against Washington's conciliatory approach for the solution of the “Negro Problem," as is widely believed in academia (2006: 20).

Nevertheless, Du Bois later described Washington's address as the "Atlanta Compromise" due to its conciliatory approach, and severely criticized his accommodationist policy for racial harmony in The Souls of Black Folk (Du Bois 1903: 31).

\section{Du Bois's Critique of Washington's Conciliatory Approach}

Though both Du Bois and Washington found it necessary to provide basic education and vocational training to black masses for their economic and social advancement, they were apparently different in their ideas about the civil rights and political actions for racial equality. While Du Bois regarded the voting rights of African Americans as indispensable for the improvement of their economic, political, social, and cultural status, Washington asked his fellow African Americans to be patient and refrain from staging political agitation for equal rights (Washington 1901: 201). Washington, a gradualist for social change, wrote that "The wisest among my race understand that the agitation of questions of social equality is the extremest folly, and that progress in the enjoyment of all the privileges that will come to us must be the result of severe and constant struggle rather than of artificial forcing" (Ibid.: 215).

We should not ignore the fact that Washington actually never failed to claim that African Americans "should not be deprived by unfair means of the franchise" (Ibid.: 201), nor should they give up their voting rights (Ibid.: 224). Despite his idea about democratic political participation of African Americans, however, Washington emphasized the priority of basic industrial training first of all for the improvement of African Americans' economic and social conditions, saying that "political agitation alone would not save him," "back of the ballot he must have property, industry, skill, economy, intelligence, and character," and "no race without these elements could permanently succeed" (Ibid.: 201).

Du Bois as well as other black leaders understood that Washington surrendered "any overt claim to voting and equal rights for African Americans” (Marable 2006: 17). Actually, Du Bois wrote in The Souls of Black Folk that Washington asked his fellow African Americans to abandon their demand for equal rights as shown below, at least temporarily: "First, political power. Second, insistence on civil rights. Third, higher education of Negro youth" (Du Bois 1903: 37). Ironically, that is why white political leaders and conservatives passionately 
welcomed Washington's speech. Du Bois kept on criticizing Washington's controversial approach, writing in one of his later works that Washington advised his fellow African Americans "to yield to disfranchisement and caste and wait for greater economic strength and general efficiency before demanding full rights as American citizens” (Du Bois 1915: 58).

Washington believed that basic industrial training was sufficient to uplift African Americans, and asked his fellow blacks to not demand higher education, in addition to voting rights or civil rights. According to Washington, African Americans would not improve their life chance through "book education" (Washington 1901: 92), academic studies such as Latin and Greek (Ibid.: 124), or geography (Ibid.: 125).

For Du Bois, in contrast, basic industrial education was not sufficient for the realization of racial equality; political participation, civil rights, culture, and racial identity, among other things, had to be protected and guaranteed for uplifting African Americans. Otherwise, African American elites, or what Du Bois called the "talented tenth," would never appear, lead, or educate black masses. Du Bois wrote that "the talented few" should enjoy the "best training" and academic education "to be the guides and servants of the vast unmoved masses who are to be led out of poverty, out of disease and out of crime" (Du Bois 1900: 64). Like Max Weber, Du Bois seemed to disregard the unorganized mass democracy and anticipated black leaders with a sense of responsibility to overcome the status quo by providing dynamic energy for social change and the reconstruction of the new democratic order ${ }^{(5)}$.

\section{Weber's High Expectation of Washington's Tuskegee Institute}

We can find some similarities between Weber's and Du Bois's views on domination and power, social change and democracy, and leaders' political roles and noblesse oblige. Weber later praised Du Bois as "the most important sociological scholar in the Southern States in America" (Scaff 2011: 101). Actually, they shared the same interest in the issue of the color line in the 20th century; while Du Bois declared that "The problem of the twentieth century is the problem of the color line" at the first Pan-African conference in London in 1900 (Du Bois 1903: xxxi), Weber sent a sympathetic letter from New York City to Du Bois on November 17, 1904, stating "I am absolutely convinced that the 'colour-line' problem will be the paramount problem of the time to come, here and everywhere in the world" (Scaff 2011: 100).

Nevertheless, it seems that Weber was more enthusiastic about Booker T. Washington's practical industrial education for African American masses at the Tuskegee Institute than Du Bois's political appeal for racial equality and civil rights. Weber was excited to visit the Tuskegee Institute while in the U.S., though Washington himself was absent at the moment to meet philanthropists for donation, and he wrote from New York City to Washington on November 6, 1904, "I was...I am sorry to say that...only at the Tuskegee I found enthusiasm in the South at all” (Scaff 2011: 109). Du Bois would have been disappointed to hear Weber's impression about the African American struggle for democracy and civil rights in the U.S.

Can we thus conclude that Weber was more interested in Washington's basic industrial education for African American masses at the Tuskegee Institute than Du Bois's theory of noblesse oblige and political struggle for racial equality? As Professor Scaff points out, Washington "tended to look away from deeply entrenched historical and social realities, the challenging threat of caste, and it could be at best only indirectly political” (Scaff 2011: 112). It appears strange that a theorist of Realpolitik like Max Weber supports Washington's 
accommodationist approach more enthusiastically than Du Bois's political appeal and action for racial equality. This question should be interesting for all sociologists who want to understand Weber's idea about traditional and legal domination based on racial hierarchy and the conditions for social change and democratization beyond the color line, which will be helpful to sociologically explain the complicated structure of racial hierarchy and the dynamics of American Democracy from broader perspectives.

\section{Notes}

(1) This paper is based on my comment on Professor Scaff's presentation about Max Weber in America in the session "Inclusion and Exclusion" organized for the 62nd annual meeting of the Kanto Sociological Society on June 22, 2014.

(2) In the 19th century, 90 percent of blacks "lived in rural areas and mostly worked in agriculture" (Marable 2006: 18).

(3) In this address, Washington justified racial segregation by saying "In all things that are purely social we can be as separate as the fingers, yet one as the hand in all things essential to mutual progress" (Washington 1901: 214).

(4) President Theodor Roosevelt invited Washington to the White House just after the publication of his 1901 work Up from Slavery that contains the Atlanta address.

(5) In his 1918 work "Parlament und Regierung im neugeordneten Deutschland: Zur politischen Kritik des Beamtentums und Parteiwesens," Max Weber suggested that democracy of immature and unorganized masses should be avoided (Weber 1988: 404), while emphasizing the importance of politicians with "passion, a feeling of responsibility, and a sense of proportion" for the advancement of national politics in his 1919 lecture "Politik als Beruf" (Ebd.: 545).

\section{References}

Anderson, Elijah 1996 "Introduction to the 1996 Edition of The Philadelphia Negro," in W.E.B. Du Bois, 1899, pp.ix-xxxvi.

Aptheker, Herbert (ed.) 1985 Unpublished Essays, Papers, Addresses, 1887-1961, Amherst: University of Massachusetts Press.

Gates, Jr., Henry Louis 1989 “Introduction: Darkly, as Through a Veil,” in W.E.B. Du Bois, 1903, pp. vii-xxix. Du Bois, W.E.B. 1899 The Philadelphia Negro: A Social Study, Philadelphia: University of Pennsylvania Press. Du Bois, W.E.B. 1900 “The Spirit of Modern Europe," in Herbert Aptheker (ed.), 1985, pp. 50-64.

Du Bois, W.E.B. 1900 "Postgraduate Work in Sociology in Atlanta University," in Herbert Aptheker (ed.), 1985, pp. 65-74.

Du Bois, W.E.B. 1903 The Souls of Black Folk, New York: Bantam Books.

Du Bois, W.E.B. 1915 The Negro, Philadelphia: University of Pennsylvania Press.

Du Bois, W.E.B. 1945 Color and Democracy, New York: Kraus-Thomson.

Du Bois, W.E.B. 1946 The World and Africa, New York: International Publishers.

Marable, Manning 2006 “Celebrating Souls: Deconstructing the Du Boisian Legacy," in Alford A. Young, Jr. et al., pp. 7-28.

Scaff, Lawrence A. 2011 Max Weber in America, New Jersey: Princeton Univ. Press.

Washington, Booker T. 1901 Up from Slavery: An Autobiography, Delhi: Ratna Sagar.

Weber, Max 1988 Gesammelte Politische Schriften, Tübingen, J.C.B. Mohr.

Young, Jr., Alford A., Manning Marable, Elizabeth Higgingbotham, Charles Lemert \& Jerry G. Watts 2006 The Souls of W.E.B. Du Bois, Colorado: Paradigm.

(Tokai University, Department of Tourism, kazuhisa-h@tokai-u.jp) 